\title{
Titae
}

32 (2017) 255-284

Ks. Zbigniew Grochowski

Uniwersytet Kardynała Stefana Wyszyńskiego, Warszawa zbigniewgrochowski@gmail.com

\section{Kogut w Biblii Z UWZgLęDNiEniem JEGO NARRACYJNEJ FUNKCJI PEŁNIONEJ W EWANGELIACH}

The Cock in the Bible, Considering its Narrative FunCtion In THE Gospels

\section{STRESZCZENIE}

Dziki ptak Gallus gallus, z czasem udomowiony (domesticus) i rozpowszechniony po świecie, stał się bardzo popularnym źródłem smacznego mięsa i jaj. Bogata symbolika z nim związana zainspirowała autorów $S T$ do zauważenia w nim zdolności do odróżniania dnia od nocy (por. Hi 38,36; 3 Mch 5,23 LXX) oraz troskliwej (a także dumnej) opiekuńczości względem powierzonych mu kur (por. Prz 30,31 LXX). Jednak kogut najbardziej jest znany z wydarzenia opisanego w NT. Wpisał się bowiem w epizod związany z Męką Pańską, gdy, zgodnie z przepowiednią Jezusa (por. Mt 26,34; Mk 14,30; Łk 22,34; J 13,38), swoim pianiem uwieńczył niechlubną postawę św. Piotra (por. Mt 26,69-75; Mk 14,6672; Łk 22,54-62; J 18,15-27). Warto jednak
SŁowa KLUCZE

kogut; pianie koguta; straż nocna; zaparcie się Piotra; skrucha; żal; gnorisma 
zauważyć, że podczas gdy w Ewangeliach synoptycznych kogut stał się znakiem rozpoznawczym (gnốrisma) uświadamiającym Piotrowi popełniony błąd i wzywającym go skutecznie do wzbudzenia natychmiastowego żalu, tak u św. Jana jego pianie jawi się jako ironiczny i smutny „ostatni głos epizodu”, a dla czytelnika staje się znakiem wskazującym na Jezusa jako Proroka pełnego mocy w swym słowie. Dzięki temu rodzi się jednocześnie nadzieja, że skoro precyzyjnie zrealizowała się zapowiedź tego dramatycznego wydarzenia, tak też z pewnością dojdzie do skutku przepowiednia męczeństwa św. Piotra (J 13,36; 21,18-19). Dzięki niemu jego upadek będzie w pełni odpokutowany, a apostoł, który stanie się przez to autentycznym uczniem Jezusa, będzie zrehabilitowany.

\section{Abstract}

A once-wild jungle bird, Gallus gallus, was at some point domesticated, spread throughout the world, and became a universally popular source of meat and eggs (Section 1). The rich symbolism associated with this creature, drawn upon already by the authors of the Old Testament, issues from two characteristics of the male bird: its ability to distinguish between day and night (cf. Job 38:36; $3 \mathrm{Mac}$ 5:23 LXX) and its caring and proud protectiveness toward the hens entrusted to him (cf. Prov 30:31 LXX) (Section 2). However, the cock is probably most famous for an event described in the New Testament: he figures in the episode within the Passion narrative where - according to the prophecy of Jesus (cf. Matt 26:34; Mc 14:30; Luc 22,34 and Jn $14: 30)$ - the cock confirms by his crow-
KEYWORDS

cock; cockcrow; night watch; Peter's denial of Jesus; repentance; gnorisma 
ing Peter's threefold denial of Jesus (cf. Matt 26:69-75; Mc 14:66-72; Luc 22:54-62; Jn $18: 15-27)$. It is worth noting that, while in the Synoptic Gospels the rooster becomes a recognizable sign (gnốrisma) by which Peter is made aware of his error and is immediately aroused to profound grief (Section 3), in John's Gospel the cock's crowing appears as an ironic and sad "last voice of the episode", becoming for the reader a sign indicating that Jesus is the Prophet whose words are full of power. This gives rise to the hope that, just as the prior announcement of this dramatic event is fulfilled precisely, the prophecy regarding St. Peter's martyrdom will likewise surely take place as spoken (cf. Jn 13:36; 21:18-19). Thanks to the future martyrdom of Peter, his fall will be fully redeemed, and the apostle, who will become the authentic disciple of Jesus, will be rehabilitated (Section 4).

Nie tylko tytuł niniejszego studium, ale także pierwsze skojarzenie rodzące się w umyśle czytelnika Pisma Świętego sprawiają, że słowo „kogut” kieruje uwagę odbiorcy ku Nowemu Testamentowi, a w nim ku scenie zaparcia się Piotra, opisanej przez wszystkich czterech ewangelistów ${ }^{1}$. Ściśle związany jest z nią epizod, w którym Jezus przepowiada apostołowi to niefortunne wydarzenie i w którym również pojawia się grecki termin aléktōr $(\text { kogut })^{2}$. Choć interesujący nas ptak wspomniany jest także na kartach ST, to jednak zaledwie trzykrotne, $i$ to raczej przelotnie, jego zacytowanie ${ }^{3}$ powoduje

1 Por. Mt 26,69-75; Mk 14,66-72; Łk 22,54-62; J 18,15-27.

2 Por. Mt 26,34; Mk 14,30; Łk 22,34; J 13,38.

3 Por. Prz 30,31 (rzeczownik aléktōr, stanowiący hapax w LXX, został oddawany w większości polskich przekładów słowem „kogut”, choć w piątym wydaniu Biblii Tysiąclecia zdecydowano się na oddanie 
brak skupienia większej uwagi na kogucie w tej części Pisma Świętego. Z kolei NT, oprócz dramatycznej sceny mającej miejsce na dziedzińcu arcykapłana, nie przywołuje już koguta w żadnym innym kontekście. Choć jest to jedyne wydarzenie opisane w NT, w którym występuje ten ptak, to jednak jego ranga sprawia, że kogut stał się nieodłącznym elementem opisów Męki Pańskiej, a więc momentu, w którym zbawienie osiągnęło swój punkt kulminacyjny. Zasługuje więc on na naszą uwagę i jemu poświęcone będzie niniejsze opracowanie.

$\mathrm{Na}$ temat przebogatej symboliki związanej z kogutem pisali już liczni autorzy, także w najnowszych publikacjach ${ }^{4}$. Owoc ich profesjonalnych badań stanowią bardzo ciekawe wnioski, z którymi warto się zapoznać w przypadku chęci zdobycia kompleksowej wiedzy na temat koguta. Nie widząc potrzeby powtarzania tych treści w niniejszym studium ${ }^{5}$, pragniemy zaznaczyć, że wstępna prezentacja interesującego nas ptaka dotyczyć będzie jego ogólnej charakterystyki oraz historii dotarcia na tereny Ziemi Swiętej i do Europy. Kolejne punkty natomiast podejmą problematykę obecności koguta w Biblii, najpierw w ST, a potem w NT. Zauważa się bowiem, że w przytoczonych wyżej publikacjach scena zaparcia się Piotra jest jedynie wspomniana, ale nie przeanalizowana, co inspiruje do uzupełnienia tej luki i jednoczesnego zastanowienia się, jaką to narracyjną funkcję pełni w Ewangeliach

greckiego terminu wyrażeniem „pies myśliwski”), Hi 38,36 (termin śekwî, hapax w TM) i 3 Mch 5,23 (alektryón, hapax w LXX).

4 Por. np. Worcester, Correspondences, 207-208; Cansdale, Animals of Bible Lands, 164-165; France, An Encyclopaedia of Bible Animals, 39-41; Feliks, „Chicken”, 613; Cooper, Zwierzęta symboliczne i mityczne, 102-104; Martin, „Watch during the Watches”, 687-688; Kobielus, Bestiarium chrześcijańskie, 137-143; Lasota-Moskalewska, Zwierzetta udomowione, 243-244; Behrouzi, „Costume, Jewish”, 265; Kowzan, „Kogut”, 121-132; Paczkowski, „Czujny zwiastun”, 77-95; Wajda, „Wybrane zagadnienia z ornitologii biblijnej”, 462-469.

5 Wyjątek stanowić będzie przywołanie symboliki związanej z kogutem w judaizmie. 
kogut. Pojawiają się przy tej okazji dodatkowe pytania: czym różni się ta funkcja w obrazie nakreślonym przez synoptyków od tej, która wyłania się z narracji opowiedzianej przez autora czwartej Ewangelii? Jak bywa wyjaśniana Markowa relacja o dwukrotnym zapianiu koguta (podczas gdy pozostali ewangeliści mówią o jednorazowym wydaniu dźwięku przez tego ptaka)? Czy w ogóle możliwa była obecność drobiu w Jerozolimie pierwszej połowy pierwszego wieku? Na te $\mathrm{i}$ inne pytania postarają się odpowiedzieć poniższe analizy.

\section{Ogólna charakterystyka koguta i jego OBECNOŚĆ W ŚWIECIE STAROŻYTNYM}

Kogut, kura domowa oraz kurczak (Gallus gallus domesticus) stanowią obecnie jeden z najbardziej rozpowszechnionych na świecie gatunków zwierząt udomowionych i są głównym źródłem zwierzęcego białka w pożywieniu człowieka ${ }^{6}$. Jego dzikim poprzednikiem był zamieszkujący dżunglę tropikalny czerwony ptak Gallus gallus. Można było go spotkać przed tysiącami lat w Azji południowej i południowo-wschodniej (głównie Chiny i Indie). Po udomowieniu go tam w szóstym milenium przed Chrystusem nastąpiła migracja kurczaka w kierunku zachodnim (III/II tysiąclecie przed Chrystusem), czego świadectwem są odkrycia jego kości w Iranie, Anatolii i Syrii, a także w Egipcie, Mezopotamii i krajach określonych mianem Południowego Lewantu (Izrael, Autonomia Palestyńska, Jordania). Kolejna faza przemieszczania się kurczaka to dotarcie do Europy (IX/VIII wiek przed Chrystusem) i szczególna intensyfikacja jego użycia na tym kontynencie. W tym okresie przyczynili się do tego

6 Treści zawarte w punkcie pierwszym zostały w dużym stopniu zaczerpnięte z opublikowanego niedawno cennego artykułu: Perry-Gal - Erlich - Gilboa - Bar-Oz, „Earliest Economic Exploitation”, 98499854. 
głównie Fenicjanie, którzy zabierali te ptaki ze sobą do swoich kolonii na Zachodzie (np. na Półwysep Iberyjski). Jednak nie tylko oni, skoro nawet w Republice Czeskiej znaleziono pozostałości kurczaka, najstarsze, jeśli chodzi o Europę centralną (VIII wiek przed Chrystusem) ${ }^{7}$.

Raczej nie było jeszcze kurczaków w Grecji w VIII wieku przed Chrystusem, skoro nie wspomina o nich Homer, ale pisze o nich już Theognis z Megary (VI wiek przed Chrystusem). Zresztą nieco wcześniej, bo w VII wieku przed Chrystusem, pojawił się kogut na greckich monetach i porcelanowych wazonach (np. w Koryncie). W V wieku przed Chrystusem Arystofanes mówił o kurczaku jako o „ptaku medyjskim”, co oznacza, że w tym okresie mógł on być importowany z Persji.

Od III wieku przed Chrystusem kogut stał się nierzadkim elementem wizerunków i wzmianek w papirusach egipskich, choć trzeba zaznaczyć, że - mimo iż Egipt posiadał drób już od ok. XV/XIV wieku przed Chrystusem - wciąż nie mówiono o nim zbyt często jako o zwierzęciu przeznaczonym do konsumpcji. Używano go do innych celów. Także w Rzymie Cicero w swoim dziele De Divinatione wspomina bitwę morską pod Drepanum z roku 249 przed Chrystusem, w której Klaudiusz Pulcher wróżył losy armii rzymskiej z zachowania koguta. Pisarze tacy jak Varro i Columella natomiast pisali o walkach kogutów.

7 Trudno jest natomiast jednoznacznie wyjaśnić sposób rozprzestrzenienia się kurczaka na kontynencie afrykańskim oraz jego dotarcie do obu Ameryk. Możliwe było przemieszczenie się tego ptaka wzdłuż doliny Nilu (z Egiptu), ale niewykluczone, że droga wiodła także przez Saharę (np. z Kartaginy) lub bezpośrednio z Indii. Najstarsze pozostałości kurczaka w Afryce pochodzą z połowy pierwszego tysiąclecia ery chrześcijańskiej i zostały znalezione w Mali (zachód kontynentu), w Nubii (północny wschód), w Afryce wschodniej oraz południowej. O tym, czy Gallus gallus domesticus istniał na terenie obu Ameryk jeszcze przed odkryciem ich przez Europejczyków, wciąż nie wiadomo. Ale kurze jaja o niebieskim kolorze skorupki, istniejące tylko w obu Amerykach i w Afryce, sugerują, że kurczaki przybyły do Ameryk właśnie z Afryki (a nie z Europy). 
Widać wyraźnie, że początkowo kogut postrzegany był powszechnie przede wszystkim jako ptak egzotyczny. Przechowywano go np. w królewskich zwierzyńcach, używano do rozmaitych rytuatów (ze względu na bogatą symbolikę z nim związaną) lub traktowano rozrywkowo (walka $z$ innymi osobnikami). Dopiero później stał się on ptakiem hodowlanym, przeznaczonym do spożycia. Popularność zyskało jego smaczne mięso, zwłaszcza gdy mowa o osobniku wykastrowanych (tzw. kapłon). Wygodna dla człowieka jest jego łatwa przystosowalność do warunków zewnętrznych. Korzystna ekonomicznie jest także jego duża „wydajność prokreacyjna": kury znoszą rocznie 230-320 jaj, a na jednego koguta przypada średnio 14 samic. Mało który kraj na świecie nie zna i nie karmi się dziś kurą domową, kurczakami, czy nawet kogutem.

Wracając do danych archeologicznych, godnymi szczególnej uwagi są odkrycia z Mareszy (Izrael) z okresu hellenistycznego (IV-II przed Chrystusem), które wraz z innymi przebadanymi 234 miejscami, znajdującymi się na terenie Izraela, Autonomii Palestyńskiej i Jordanii, są świadectwem traktowania kurczaków już głównie ekonomicznie i kulinarnie (a więc nie symbolicznie i rytualnie), co oznacza przypisanie im nowej roli w tym okresie w krajach leżących na wschodnim, azjatyckim wybrzeżu Morza Śródziemnego. Kości kurczaka znalezione w Mareszy stanowią aż 29\% wszystkich gatunków żywego inwentarza i w $80 \%$ były to osobniki dojrzałe. Inne badania dowiodty, że niektóre kury w Mareszy znosiły jaja i były w okresie ich wysiadywania. Ponadto zaskakującym było odkrycie faktu, że ilość kości samic dwukrotnie przewyższa ilość pozostałości po samcach (co dowodzi nastawienia mieszkańców Mareszy na pozyskiwanie jaj do bezpośredniego spożycia lub handlu $)^{8}$. Przypuszcza się także, że kurczaki

8 Zazwyczaj bywało odwrotnie: ilość kogutów i kurczaków (samców) przewyższała swą liczbą ilość kur. Gdy natomiast mowa o handlu, transport osobników tego gatunku oraz jego jaj stał się operacją o wie- 
z Mareszy były przechowywane w fermach, co wzmacnia tezę o ich masowej hodowli i przeznaczeniu na spożycie.

Ogólnie zatem mówiąc, przed okresem hellenistycznym ekonomiczna i konsumpcyjna eksploatacja kurczaka była raczej sporadyczna, a dopiero w tym czasie jego obecność w gospodarstwach (i na stole zasiadającego przy nim człowieka) wyraźnie wzrosła. Większym uznaniem cieszyło się więc już mięso kurczaka oraz jaja znoszone przez kury niż walki kogutów czy inne, rytualne cele, na które przeznaczano Gallus gallus domesticus. Tym samym kraje należące do Południowego Lewantu stały się pomostem między wstępnym udomowieniem koguta, kury oraz kurczaka w dalekiej Azji a ich adaptacją w ekonomii Europy i sprawiły, że doceniono je jako opłacalny handlowo i smaczny kulinarnie gatunek ptaka domowego. Do tej - już raczej ekonomicznej - ekspansji najbardziej przyczynili się Rzymianie, którzy wnieśli do Europy także inne gatunki jadalnych zwierząt, takie jak: perliczka (Numida Meleagris), bażant (Phasianus colchicus) czy królik (Oryctolagus cuniculus) $)^{9}$.

le prostszą w porównaniu do przemieszczania większych zwierząt. Ponadto kurczaki potrzebują mniej wody i pokarmu niż większe sztuki bydła, dzięki czemu mogły być hodowane przez uboższe rodziny. 9 W podobnym duchu opisują pochodzenie koguta i historię jego wędrówki po świecie, a także podstawowe cechy charakteryzujące tego ptaka, następujący autorzy: Feliks, The Animal World, 59 (tu pojawia się m.in. wzmianka o odnalezionej w Mizpeh pieczęci z okresu Pierwszej Świątyni zawierającej wizerunek koguta, por. również: Feliks, „Chicken”, 613); Cansdale, Animals of Bible Lands, 163-164 (autor zastanawia się m.in., czy Izraelici spotkali się po raz pierwszy z kogutem już podczas niewoli egipskiej czy może ptak ten dotarł do Ziemi Świętej bezpośrednio z Indii bądź został podarowany przez króla perskiego po niewoli babilońskiej); West - Zhou, „Did Chickens Go North?”, 515-533; Firmage, „Zoology”, 1145; Cooper, Zwierzeta symboliczne i mityczne, 103; Lasota-Moskalewska, Zwierzęta udomowione, 240-243; Al-Nasser et al., „Overview of Chicken”, 285-300; Liu et al., „Multiple Maternal”, 12-19; Tixier-Boichard - Bed'hom - Rognon, „Chicken domestication”, 197-204; Paczkowski, „Czujny zwiastun", 81 (autor, oprócz wspomnienia pieczęci z Mizpeh, odnosi 


\section{Kogut w Starym Testamencie i judaizmie}

Wspomniane już we wstępie trzykrotne pojawienie się koguta w ST stanowi pewną ciekawostkę filologiczną. Okazuje się, że określenie interesującego nas ptaka nie jest jednoznaczne, zwłaszcza jeśli chodzi o język hebrajski ${ }^{10}$.

Rzeczownikiem, który nie sprawia kłopotu w swej identyfikacji, jest obecne w Hi 38,36 słowo śekwî, rozumiane także w klasycznym języku hebrajskim przede wszystkim jako kogut ${ }^{11}$. Biblijny mędrzec, wkładając w usta YHWH rozliczne pytania retoryczne mające na celu ukazanie wielkości Boga, w pewnym momencie pyta: „kto dał [...] kogutowi rozum/umiejętność [bināh]?”. O tym, na czym miałaby polegać ta zdolność, mówi już Targum Jerozolimski, formułując treść porannej modlitwy: „Kto dał dzikiemu kogutowi zrozumienie, aby chwalił swego Pana? Gdy człowiek słyszy pianie koguta, powinien mówić: Niech będzie błogosławiony Ten, który dał kogutowi inteligencję do odróżniania dnia od nocy” (Bərakôt 60 b) ${ }^{12}$. Dlatego też „w talmudycznej

się także do przedmiotów znalezionych w biblijnym Gibeonie, na których figuruje podobizna koguta).

10 Także w greckiej Septuagincie występują dwa lekko zróżnicowane warianty: aléktōr (Prz 30,31) i alektryōn (3 Mch 5,23), choć oba o tym samym znaczeniu: „kogut” (por. Abramowiczówna, „aléktōr”, 83 i Abramowiczówna, „alektryốn”, 83). Moulton i Howard (A Grammar of New Testament, II, 365) twierdzą, że pierwotna forma aléktōr została zastąpiona w grece attyckiej terminem alektryốn, choć powróciła ona do swego użycia w dialekcie koine (ten natomiast stanowił bazę dla tekstu oryginalnego NT).

11 Por. Clines, „śekwî”, VIII, 148. Autor podaje kolejne znaczenia tego terminu: 'umysł' (warto zauważyć, że to - ulokowane na drugiej pozycji - słowo może mieć coś wspólnego z intuicją natchnionego autora, zawartą w Hi 38,36), 'mgły, oko, błyskawice, zjawisko na niebie, (planeta) Merkury’. Ostatnia myśl z kolei nawiązuje być może do mitologicznego poglądu, że koguty ciągnęły rydwan Hermesa (Merkurego). Por. Cooper, Zwierzęta symboliczne i mityczne, 103.

12 Por. Feliks, The Animal World, 59; Feliks, „Chicken”, 613. Paczkowski („Czujny zwiastun”, 81) komentuje: „Istotnie, trudno oprzeć się 
tradycji judaistycznej koguta uważano za mistrza grzeczności"13 (bo anonsuje słońce) i najwspanialszego głosiciela chwały Najwyższego - gdy Bóg udaje się o północy na spotkanie pobożnych w raju, wszystkie drzewa w niebie stają do adoracji, a ich pieśni w pewnym momencie budzą koguta, który, w odpowiedzi, wielbi Pana śpiewem siedmiu hymnów ${ }^{14}$. O kogucie jako zwiastunie poranka mówi także $3 \mathrm{Mch}$ 5,23, gdzie występuje grecki rzeczownik alektryốn. Tak jak

wrażeniu, że natura obdarzyła koguta swoistym instynktem. To ten ptak pełnił rolę prawdziwego stróża domu, godnego najwyższego podziwu ze względu na czujność i poczucie obowiązku".

13 Kobielus, Bestiarium chrześcijańskie, 138.

14 France, An Encyclopaedia of Bible Animals, 41. Ten pozytywny aspekt działania koguta zostaje wzmocniony przeświadczeniem (obecnym także poza Izraelem), że jego pianie przepędza złe duchy błąkające się w ciemności po świecie (por. France, An Encyclopaedia of Bible Animals, 41; Derrett, „The Reason”, 143; Mędala, Ewangelia wedtug świętego Jana, 203). Ginzberg (The Legends, 44-45) podaje tę legendę in extenso: "Great among singers of praise are the birds, and greatest among them is the cock. When God at midnight goes to the pious in Paradise, all the trees therein break out into adoration, and their songs awaken the cock, who begins in turn to praise God. Seven times he crows, each time reciting a verse. The first verse is: «Lift up your heads, O ye gates; and be ye lift up, ye everlasting doors, and the King of glory shall come in. Who is the King of glory? The Lord strong and mighty, the Lord mighty in battle». The second verse: «Lift up your heads, O ye gates; yea, lift them up, ye everlasting doors, and the King of glory shall come in. Who is this King of glory? The Lord of hosts, He is the King of glory». The third: «Arise, ye righteous, and occupy yourselves with the Torah, that your reward may be abundant in the world hereafter». The fourth: «I have waited for Thy salvation, O Lord!». The fifth: «How long wilt thou sleep, O sluggard? When wilt thou arise out of thy sleep?». The sixth: «Love not sleep, lest thou come to poverty; open thine eyes, and thou shalt be satisfied with bread». And the seventh verse sung by the cock runs: «It is time to work for the Lord, for they have made void Thy law»”. Pieśni śpiewane przez koguta nawiązują do niektórych urywków biblijnych, por. kolejno: Ps 24,7-10; Rdz 49,18; Prz 6,9; 20,13; Ps 119,126. Por. Bauckham, The Jewish World, 415). 
śekwî stanowi hapax legomenon w Biblii Hebrajskiej, podobnie alektryón występuje jeden tylko raz w LXX. Ksiądz Popowski przetłumaczył wspomniany werset następująco: „Gdy tylko kogut zapiał przed brzaskiem, Hermon ustawił słonie w pełnym ekwipunku przy wielkiej kolumnadzie"15. Ponownie zatem widać skojarzenie tego ptaka z jego charakterystyczną czynnością: pianie u kresu nocy bądź na początku budzącego się dnia ${ }^{16}$.

Warte szczególnej uwagi jest jeszcze jedno pojawienie się koguta w ST. Prz 30,31 (LXX) mówi o „kogucie, co dumnie chodzi wśród kur". Jako przykład postaci wykonujących wspaniały krok podczas stąpania (Prz 30,29) przywołany jest jeszcze lew $(30,30)$, kozioł oraz król, przy którym znajduje się jego lud $(30,31)$. Podczas gdy wersja grecka Księgi Przysłów nie sprawia w tym momencie trudności translacyjnych nawiązując jednocześnie w pewnym sensie do etymologii terminu aléktōr (hapax w LXX) ${ }^{17}$ - zrozumienie tekstu hebrajskiego opiera się na swoistej dedukcji. Nie występuje tu bowiem znany nam już rzeczownik śek $w \hat{\imath}$, ale zwrot zarzîr motnáyim, tłumaczony jako „(ktoś) o mocnych/przepasanych

15 Septuaginta czyli Grecka Biblia Starego Testamentu wraz z ksiegami deuterokanonicznymi i apokryfami żydowskimi oraz onomastykonem (tłum. ks. Remigiusz Popowski) (Warszawa: Vocatio 2014) ad loc.

16 „Autor trzeciej księgi Barucha [= Grecka Apokalipsa Barucha, apokryf Starego Testamentu - przyp. autora], przypisywanej uczniowi proroka Jeremiasza, tłumaczy, że kogut nigdy nie spóźnia się na spotkanie poranka, gdyż budzi go legendarny ptak Feniks - symbol zmartwychwstania. Tradycja żydowska i chrześcijańska posługują się wyrażeniem «o pianiu koguta» (łac. gallicinium), co znaczy bardzo wcześnie rano”. Paczkowski, „Czujny zwiastun”, 81.

17 Sugeruje się pochodzenie rzeczownika „kogut” od czasownika aléksō („oddalać, odganiać, odpierać, bronić, chronič”) w nawiązaniu do jego funkcji opieki nad kurami i ich ochrony; por. Rocci, „aléktōr”, 66; Rocci, „aléksō”, 67; Montanari, „alektōr”, 123; Montanari, „aleksō”, 123-124; Moulton - Howard, A Grammar of New Testament, II, 365; Romizi, „aléktōr”, 57: „(vedi aléksō: tengo lontano, difendo e suffisso nominale -tör a indicare chi compie l'azione) colui che allontana, che difende: gallo". 
lędźwiach"18. Choć do desygnatu tego określenia odnosić się może kilka różnych zwierząt, niewątpliwie kogut także może być brany pod uwagę. A zatem podczas gdy tekst grecki ST w stu procentach opowiada się za kogutem w Prz 30,31, jego wersja hebrajska czyni to na zasadzie dużego prawdopodobieństwa. Oznacza(łoby) to, że trzecie pojawienie się koguta w ST nie ma już związku z jego porannym obwieszczaniem nadchodzącego dnia, lecz ze sposobem jego (majestatycznego) poruszania się oraz pełnieniem funkcji obronnej względem podopiecznych (kur).

Istnieją jeszcze inne terminy hebrajskie stosowane na określenie koguta, ale spotkać je można w literaturze pozabiblijnej. W Misznie jest on określony mianem tarneḡôl (a samice - tarneḡôlet), który pochodzi od sumeryjskiego

18 Clines, „zarzîr”, III, 137. Ten (przypuszczalnie) przymiotnik oznaczający "mocny, przepasany” przybiera w Prz 30,31 formę status constructus i w połączeniu z terminem "lędźwie” funkcjonuje jako rzeczownik wskazujący najprawdopodobniej na charta (ang. greyhound) albo na koguta lub kogucika (ang. cockerel). Nietrudno zauważyć, że w piątym wydaniu Biblii Tysiąclecia - w przeciwieństwie do poprzednich wydań - tłumacze nie poszli za pierwszą intuicją („pies myśliwski”). W Biblii Gdańskiej (1633) i w niektórych przekładach niepolskich pojawia się jeszcze inne słowo: „koń, rumak”. Swoiste kuriozum stanowi tu czwarte wydanie Biblii Tysiąclecia, które mówi zarówno o „kogucie”, jak i „koniu bojowym”, obu zwierzętach będących jednoczesnym tłumaczeniem zarzîr motnáyim. Jednak większość przekładów współczesnych, podobnie jak przede wszystkim Septuaginta, opowiada się za drugą z propozycji, obecnych w monumentalnym dziele Clinesa. Autor wzmacnia tę tezę sugestią, że w Prz 30,31 TM miała prawo mieć miejsce korekta (emendatio). Nie jest więc wykluczone, że motnayim zastąpiło oryginalne mitnaśśé ('podniosły' [exalted] w sensie: „kroczący dumnie, puszący się, pyszniący się" [strutting]), co sprawia, że sens tej hipotetycznej, niepoprawionej lekcji TM („ktoś przepasany [zarzîr] dumnie kroczący [mitnaśśse']”) byłby znacznie bliższy treści Prz 30,31 w jego wersji greckiej. Tę dyskusję wieńczy Feliks (The Animal World, 59) stwierdzeniem: „The Talmud mentions «fights of Zarzîrîm», where, probably, cock fights are meant" (podkreślenie moje - Z.G.). 
tarlugal. Także géber desygnuje koguta ${ }^{19}$, co stało się powodem nieporozumienia w łacińskim tłumaczeniu Iz 22,17: hebrajskie zdanie, zawierające rzeczownik géber oznaczający „człowieka” w biblijnym i klasycznym języku hebrajskim ${ }^{20}$ przełożone na: „Oto Pan zrzuci cię, cztowiecze, z wielkim rozmachem i uchwyci cię jednym ruchem" (piąte wydanie Biblii Tysiąclecia) zostało przez Hieronima oddane następująco: „ecce Dominus asportari te faciet sicut asportatur gallus gallinacius” („Oto Pan pochwyci cię, tak jak się chwyta koguta" $)^{21}$. Ów géber sprawia także, iż współcześnie używa się koguta jako substytut człowieka (jego grzechów) w rytuale związanym z yôm kippûr : obraca się go nad głową mężczyzny (a kurę nad głową kobiety), by potem przeznaczyć na rytualne zabicie ze świadomością, że dzięki temu człowiek będzie mógł jeszcze długo wieść swoje życie w pokoju ${ }^{22}$.

Warte przywołania na koniec niniejszego punktu jest jeszcze jedno znaczenie koguta mające wpływ na zwyczaje żydowskie. Jako że dzięki swej wydajnej płodności symbolizuje on prokreację, stało się częścią ceremonii małżeńskiej prowadzenie przed parą nowożeńców koguta i kury, jak gdyby chciało

19 Por. Feliks, „Chicken”, 613.

20 Por. Clines, „géber”, II, 313-314.

21 Por. Paczkowski, „Czujny zwiastun”, 81. Także w samej literaturze rabinicznej obecna jest dyskusja dotycząca dwuznaczności w rozumieniu terminu géber. Widoczna jest ona np. w Gemarze do traktatu Yôma 20b z Talmudu Babilońskiego (por. Martin, „Watch during the Watches", 695; Bauckham, The Jewish World, 416, p. 64).

22 Scherman - Goldwurm - Gold, Jom Kippur, 46-47: „The form of the ritual calls for a chicken to be moved in a circular motion around the penitent's head. The chicken is later slaughtered (symbolizing the concept that the sinner deserves to give up his soul for not having used it to do God's will) and either the chicken or its cash value is given to the poor, for charity is an indispensable part of the repentance - and the combination of the two can achieve atonement [...]. Technically, any animal should be acceptable for the kaparos ritual. However [...] [c] hickens were chosen because the Hebrew word géber means both man and rooster. [...] [W] hite rooster was taken for a male and white hen for a female". 
się wypowiedzieć życzenie: „bądźcie płodni i rozmnażajcie się jak drób/kurczaki" (Gîtțîn 57a; Bərakôtôt 22a) ${ }^{23}$. A zatem wraz z biblijną pochwałą koguta za umiejętne rozróżnianie dnia od nocy oraz dumne kroczenie wśród kur i ich odważną ochronę przed niebezpieczeństwem - a także jego „zdolność i użyteczność ekspiacyjną" podczas yôm kippûr - również płodność koguta wpisuje się w pozytywny obraz tego ptaka, obecny w ST i niektórych zwyczajach obecnych w judaizmie.

\section{KogUt U SYNOPTYKÓW - ZNAK ROZPOZNAWCZY (GNÓ́RISMA) DANY PIOTROWI}

Umieszczenie Ewangelii synoptycznych oraz dzieła Janowego w odrębnych punktach niniejszego opracowania wynika nie tylko z ogólnej świadomości różnic istniejących między tymi księgami. Okazuje się, że także kogut przedstawiony jest w nich trochę inaczej, to znaczy pełni w nich nieco inną funkcję narracyjną.

Dramatyczna historia, którą Piotr przeżył na dziedzińcu arcykapłana (Mt 26,69-75; Mk 14,66-72; Łk 22,54-62; $\mathrm{J} 18,15-27)$, została mu uprzednio przepowiedziana przez samego Chrystusa (Mt 26,34; Mk 14,30; Łk 22,34; J 13,38). Podczas Ostatniej Wieczerzy (jak relacjonują Łukasz i Jan) lub zaraz po niej (jak utrzymują Marek i Mateusz), gdy już wszystkim było wiadome, że jeden z uczniów wyda Mistrza

23 Por. Feliks, „Chicken”, 613; Cansdale, Animals of Bible Lands, 164165; Cooper, Zwierzęta symboliczne i mityczne, 103; Paczkowski, „Czujny zwiastun”, 81-82. Ostatni z autorów, choć potwierdza istnienie tej tradycji, błędnie przypisuje rzymskim legionistom fakt ślubnego pochodu z kurą i kogutem w miejscowości Tur Malka: powstałe tam później rozruchy spowodowane były tym, że grupa rzymskich żołnierzy stanęła na drodze Żydów świętujących właśnie ślub oraz wesele i zabrała im koguta oraz kurę, za co żołnierze zostali pobici, co ostatecznie doprowadziło do zniszczenia tego miasta przez legionistów. 
w ręce oprawców oraz że fakt ten może zakończyć się śmiercią (tzn. Jego krew właśnie teraz może być przelana przez jakiegoś agresora), Jezus zapowiada moment zgorszenia apostołów i ich zwątpienie. Św. Piotr, tradycyjnie, uprzedza wszystkich swą reakcją i energicznie zapewnia o swej lojalności i wierności. Ma się ona wyrazić nie tylko w gotowości na pójście do więzienia z Chrystusem, ale nawet na śmierć wraz z Nim. Jezus jednak pozbawia swego ucznia wszelkich złudzeń: „Piotrze, jeszcze dziś, tej nocy, zanim kogut [dwa razy] zapieje, ty trzy razy się Mnie wyprzesz"24. Okazuje się, że deklaracja apostoła opiera się na kruchych fundamentach, a z największym upadkiem, jaki w swym życiu przeżyje rybak z Galilei, związana będzie postać koguta, a precyzyjniej jego zapianie.

Wczytując się uważnie w dzieło Markowe, zauważamy intrygującą wzmiankę o dwukrotnym zapianiu koguta. Wprawdzie Kodeks Synajski nie zawiera stów „dwa razy” w Mk 14,3025 (oraz „powtórnie” w Mk 14,72a ${ }^{26}$ ), a wraz z nim także nawet Kodeks Watykański nie podaje w Mk 14,68, że „kogut zapiał” (po raz pierwszy z dwóch) ${ }^{27}$, to jednak nie ulega wątpliwości, że narracja Markowa - w przeciwieństwie do pozostałych Ewangelii - sugeruje dwukrotne wydanie dźwięku przez koguta. Nie można bowiem pominąć danych pochodzących z innych, licznych kodeksów, nawet jeśli są one mniej autorytatywne niż oba wspomniane przed chwilą. A fakt ten rodzi pytanie o przyczynę różnicy powstałej między narracją Markową a opisem przekazanym nam przez pozostałych ewangelistów.

24 Słowa te są kompilacją wypowiedzi Jezusa, przytoczonej przez wszystkich czterech ewangelistów.

25 Mk 14,30: „Odpowiedział mu Jezus: «Zaprawdę, powiadam ci: dzisiaj, tej nocy, zanim kogut dwa razy zapieje, ty trzy razy się Mnie wyprzesz»”. Mk 14,72a: „I w tej chwili kogut powtórnie zapiał”.

27 Mk 14,68: „Lecz on zaprzeczył temu, mówiąc: «Nie wiem i nie rozumiem, co mówisz». I wyszedł na zewnątrz do przedsionka, a kogut zapiat". 
Gdy do tej problematycznej sprawy doda się jeszcze zupełnie nieoczekiwane podejrzenie, iż kogut mógł być zwierzęciem rytualnie nieczystym ${ }^{28}$, rodzi się sugestia, że ewangelista, mówiąc o dwukrotnym zapianiu koguta, mógł mieć na myśli nie tyle wydanie dźwięku przez żywego ptaka (którego, zakładając, nie byłoby wówczas w Jerozolimie), ale zakrzywioną trąbkę (buc[c]ina), w którą dęto na początek i na koniec kolejnych straży nocnych, dając żołnierzom sygnał o mającej miejsce zmianie ich warty ${ }^{29}$. Jedna ze straży nocnych nosiła bowiem greckie miano alektorofönia (łac. gallicinium), czyli „pianie koguta”. Innymi były: poprzedzające jąopsé („wieczór”) i mesonýktion („północ”) oraz następujący później prōi („poranek”), wymienione choćby w Mk 13,35 Jako że powszechnie przyjmuje się, iż trwały one kolejno w godzinach: 18-21, 21-24, 0-3 i 3-6, trąbka ta obwieszczała ich zmiany co trzy godziny, brzmiąc - według powyższej

28 Wniosek taki nasuwa się w związku z treścią traktatu Miszny Bābā’ Qammā’ 7,7, gdzie jest mowa o całkowitym zakazie hodowli drobiu w Jerozolimie, a poza Świętym Miastem - w domach, gospodarstwach kapłanów. Informacja ta wywołuje zdziwienie, gdyż Pwt 14,11-18.20 zawiera listę ptaków rytualnie nieczystych, a wśród nich nie ma kury czy koguta. Cansdale (Animals of Bible Lands, 161) dopowiada, że według starożytnej tradycji żydowskiej ptakiem nieczystym jest ten, który żywność chwyta pazurami, a czystym posiadający dodatkowy pazur i wole, i u którego może być zdarta, odcięta skóra z żołądka (jak np. u kurczaka). Paczkowski („Czujny zwiastun”, 82) słusznie poddaje krytyce przekaz Miszny: „dokładne ustalenie czasu powstania powyższych tekstów jest prawie niemożliwe, trudno więc wyrokować o tym, czy tego typu surowych zakazów przestrzegano w czasach Chrystusa". Autor podaje przybliżoną datację: Miszna - rok ok. 200 po Chrystusie, Talmud Jerozolimski -ok. 400 po Chrystusie, Talmud Babiloński -ok. 500 po Chrystusie. Por. Paczkowski „Czujny zwiastun”, 82 p. 28 . Z podobną rezerwą do BQ 7,7 podchodzi Mędala (Ewangelia wedtug świętego Jana, 202).

29 Por. Morris, The Gospel, 673, p. 61; Mędala, Ewangelia wedtug świętego Jana, 202. Taką hipotezę wysunął przed niemal stu laty Mayo („St. Peter's Token”, 367-370).

30 „Czuwajcie więc, bo nie wiecie, kiedy pan domu przyjdzie: $\mathrm{z}$ wieczora czy o północy, czy o pianiu kogutów, czy rankiem”. 
hipotezy związanej z Markowym opisem Męki Pańskiej - najpierw o północy (Mk 14,68), a potem o 3 nad ranem $(\mathrm{Mk} 14,72)^{31}$.

Nie ma jednak potrzeby obawiać się braku obecności koguta w Jerozolimie czasów Chrystusa. Na jej korzyść przemawia nie tylko fakt, iż „Rzymianie rozpowszechnili go

31 Stanowczo sprzeciwia się określaniu czterech straży nocnych według wspomnianych wyżej nazw Martin („Watch during the Watches”, 685-701) i oponuje zwłaszcza tezie, jakoby gallicinium miało przypadać na godziny 0-3. Autor, powołując się na takich starożytnych pisarzy, jak Homer, Ezop, Arystofanes, Strabon, Pliniusz Starszy i Lukian z Samosaty, utrzymuje, że pianie koguta należy wiązać tylko i wyłącznie z nadchodzącym światłem dnia (a nie ze środkiem nocy). Odrzuca zatem także wyniki obserwacji Kosmali (por. Kosmala „The Time”, 118-120; Kosmala „The Time [II]”, 132-134), a przychyla się ku wnioskom podobnym do tych, jakie sformułował Lagrange (por. Lagrange, Évangile Marc, 599, p. 2; Lagrange, L'Évangile de JésusChrist, 385, p. 30), sugerując, że koguty w Jerozolimie czasów Jezusa piały w okresie Paschy między godziną 2-3 a świtem, ich współczesne pianie między północą a godz. 3 zaś wywołane jest sztucznym światłem elektrycznym wprowadzającym w błąd dzisiejsze koguty (także autor niniejszego studium niejednokrotnie słyszał pianie kogutów ok. godz. 1-2 podczas swych nocnych spacerów wokół Starej Jerozolimy). Według Martyna problem tkwi nie tyle w zaadoptowaniu przez Żydów rzymskich czterech straży nocnych (w miejsce własnych trzech, por. Sdz 7,19, gdzie jest mowa o „środkowej”, a więc tym samym nieparzystej liczbie straży nocnych), ale w przypisaniu im później przez ewangelistów błędnych nazw, co jest znakiem oraz skutkiem dużej odległości czasowej i mentalnościowej między przedmarkową tradycją, związaną ze Świątynią Jerozolimską, a ostateczną redakcją Ewangelii. Naszym zdaniem spór o czas, w którym pieją koguty, traci jednak ostatecznie swą moc argumentacyjną, gdyż, jak słusznie stwierdził już starożytny pisarz Cyceron: „Quod autem est tempus, quo illi non cantent, vel nocturnum vel diurnum” („Który zatem jest [to] czas, w którym on [kogut] by nie śpiewał/piał, czy to nocą, czy za dnia?”) (De Divinatione, 434 [\$ II.26.56]). Dlatego też - wspominając swoją podróż do Jerozolimy - Lattey („A Note on Cockcrow”, 53) z humorem stwierdza: „a Dominican father of the Ecole Biblique [...] replied with a smile that he would be prepared to produce cockcrow at any time desired". 
we wszystkich swoich koloniach"32 (a zatem zapiać mógł przynajmniej któryś z kogutów znajdujących się na jakimś podwórku zamieszkiwanym przez przybyszów z Italii), ale obecności drobiu w Jerozolimie wczesnego okresu rzymskiego (lata 63 przed Chrystusem - 70 po Chrystusie) dowodzą najnowsze dane archeologiczne. Nie musimy zatem opierać się już tylko na domysłach ${ }^{33}$, lecz dowody przynoszą najświeższe wykopaliska ${ }^{34}$.

32 Cooper, Zwierzęta symboliczne i mityczne, 103; podobnie stwierdza Cansdale (Animals of Bible Lands, 163, 165): „There is no doubt about the presence of domestic fowls in Palestine in NT times [...] It had become economically important and was regularly eaten by the Romans who took it everywhere, even as far as Britain".

33 Jeremias, Jerusalem zur Zeit Jesu, 53-54: „Im Ganzen kommen wir zu dem Urteil, dass man Hühner in Jerusalem zog [...] Es ist daher auch wahrscheinlich, dass man Hühner auf dem Jerusalemer Markte verkaufte".

34 W opublikowanym w tym roku artykule „The Faunal Evidence from Early Roman Jerusalem” (strony 98-117, zwłaszcza 102-103, 107), archeologowie Spiciarich, Gadot i Sapir-Hen opisują efekt swoich trzyletnich badań. Przeprowadzając wykopaliska w Mieście Dawida i przeszukując teren położony ok. $200 \mathrm{~m}$ na południe od źródła Gihon, natknęli się na pozostałości wysypiska śmieci, w którym znajdowało się wiele odpadków z potraw mieszkańców Jerozolimy, które to potrawy zawierały kości zwierząt. Okazuje się, że 92\% wszystkich kości (a znaleziono ich w tym miejscu 5701 fragmentów) stanowi pozostałość żywego inwentarza, z którego $69 \%$ to owce i kozy, 13\% należy do bydła, a 7\% to kości Gallus gallus domesticus. $\mathrm{Z}$ racji przestrzegania zasad koszerności (por. Pwt 14,3-21; Kpł 11,147) nie znaleziono tam, zgodnie z oczekiwaniem, pozostałości po świniach, wielbłądach, zającach czy borsukach. Spoglądając zaś na to zagadnienie z innej strony, spośród kości znalezionych tam ptaków aż 97\% należy do kurczaków (a zwłaszcza kur, bo kości samic dominują w tym miejscu). Pozostałe 3\% to kości kuropatw, gęsi i kaczek. Nieobecne natomiast są pozostałości po gołębiach, co może oznaczać, że ich funkcja miała charakter czysto kultyczny i związana była wyłącznie ze świątynią. Jako że przeważa ilość elementów noszących mięso, kurczaki i kury przeznaczone były do konsumpcji (,these remains come from slaughtered poultry rather than from other activities, such as cockfighting", Spiciarich - Gadot 
Nie mając więc wątpliwości co do prawdziwego zapiania konkretnego i realnego koguta możemy tylko zastanawiać się, dlaczego autorzy Ewangelii według świętego Mateusza i Ewangelii według świętego Łukasza (oraz Ewangelii według świętego Jana) nie mówią o podwójnym pianiu tego ptaka. Wydaje się, że Marek jest w swym opisie bardziej precyzyjny, bo ptak ten rzeczywiście miał prawo wydać z siebie głos dokładnie dwa razy w czasie, gdy Piotr przebywał na dziedzińcu arcykapłana, a ewangelista mógł chcieć nie pominąć żadnego szczegółu, i w tym sensie ma rację, gdy mówi o dwukrotnym zapianiu koguta. Ale także Mateusz i Łukasz mają swoją rację: opuszczają wzmiankę o pierwszym pianiu, aby nie komplikować opowiadania ${ }^{35}$. Jeśli bowiem kogut piał dwa razy - a po pierwszym z nich Piotr w ogóle nie zareagował jakąkolwiek refleksją i opamiętaniem się - to można przypuszczać, że on tego dźwięku w ogóle nie usłysza1 ${ }^{36}$. Prawdziwego znaczenia nabiera dopiero drugie, kluczowe pianie koguta. Dopiero ono informuje o definitywnym, potrójnym zaparciu się Mistrza. Także Piotr dopiero w tym momencie usłyszał ów charakterystyczny dźwięk i, jak zgodnie relacjonują synoptycy, „wybuchnął płaczem” (Mk 14,72) lub „wyszedł na zewnątrz i gorzko zapłakał" (Mt 26,75; Łk 22,62).

Tym co łączy (nieznacznie zróżnicowane) Ewangelie synoptyczne jest funkcja, jaką w perykopie o zaparciu się

-Sapir-Hen, „The Faunal Evidence”, 110). Potwierdzone tym samym zostają wnioski, wyciągnięte już w punkcie pierwszym niniejszego studium, a zwłaszcza także fakt, że Jerozolima czasów Chrystusa bardzo dobrze musiała znać dźwięk piejących kogutów.

35 Por. Brown, The Death of the Messiah, 605, p. 32: „Matt and Luke $[\ldots]$ have omitted «a second time» [...] [T] hey would have seen it as an unnecessary complication".

36 Pierwsze zapianie przedstawia zatem wartość tylko dla czytelnika Ewangelii, który zauważa, że oto zaczyna wypełniać się zapowiedź Jezusa z Mk 14,30 i z tym większym zainteresowaniem śledzi ciąg dalszy opowiadania (por. Pesch, Il vangelo di Marco, 659: „l'accenno [...] al (primo) canto del gallo [...] aumenta la tensione nell'attesa degli avvenimenti successivi”). 
św. Piotra pełni kogut. Choć jest on elementem użytecznym również dla czytelnika Ewangeliii ${ }^{37}$, to jednak - na poziomie narracji - jest on bardzo ważnym sygnałem także dla samego ucznia Chrystusa, właśnie poddanego próbie. Staje się bowiem również dla Piotra znakiem rozpoznawczym (gnốrisma) wypełnienia się proroctwa Jezusa, a więc także obwieszczeniem prawdy o moralnym upadku apostoła: o jego słabości, niewierności, braku lojalności względem Mistrza ${ }^{38}$. Okazuje się jednak, że znak ten - oprócz potwierdzenia faktu, że precyzyjnie zrealizowało się słowo Jezusa - osiągnął swój dodatkowy, pozytywny efekt: wywołał w Piotrze natychmiastowy żal i zainspirował go do szczerego płaczu nad swym grzechem. Pełne dramatyzmu zaklinanie się i wypieranie (pod przysięgą) swej przynależności do Jezusa, widoczne zwłaszcza u Mateusza i Marka (por. Mt 26,74; Mk 14,71), przerodziło się w równie dynamiczne wyrażenie swego żalu: „i wybuchnął płaczem” (Mk 14,72).

\section{Kogut w Ewangeli wedeug Św. Jana - Ostatni „GŁOS” EPIZODU, GNŌRISMA DLA CZYTELNIKA}

Warto zauważyć, że myśl wieńcząca trzeci punkt niniejszego opracowania nie jest adekwatna do czwartej Ewangelii. Perykopa opisująca scenę przesłuchania Jezusa przez arcykapłana oraz mające miejsce dokładnie w tym samym czasie trzykrotne zaparcie się Piotra (J 18,15-27) ${ }^{39}$, nie kończy

37 Dzięki niemu łatwo jest przekonać się podczas lektury, że Jezusowe słowa spełniają się perfekcyjnie na osobie Piotra.

38 Aretius, In Novum Testamentum Commentarii, 1009: „Petro datus fuit $\gamma \nu \dot{\omega} p ı \mu \alpha$ certissimum sui lapsus. Iam canit, animadvertit igitur Petrus lapsum contigisse". Por. Liddell - Scott - Jones - McKenzie, "gnốrisma”, 355 („that by which a thing is made known, mark, token”). Dzięki zastosowaniu metody przypominającej kinematograficzną „stopklatkę" (por. J 18,18: „Wśród nich stał także Piotr i grzał się”, J 18,25: „A Szymon Piotr stał i grzał się”), św. Jan najdoskonalej 
się ukazaniem żalu apostoła. Wydarzeniem finalizującym tę scenę, stanowiącym jednocześnie „ostatni głos narracji”, staje się tym razem zapianie koguta zastępujące oczekiwane danie świadectwa prawdzie przez ucznia ${ }^{40}$. Milczenie Piotra ${ }^{41}$,

z ewangelistów zdołał uzyskać efekt synchronii w przedstawieniu obu epizodów. Autorzy Ewangelii według św. Mateusza oraz Ewangelii według św. Marka, celem „przeplecenia” ze sobą tych zdarzeń, najpierw zaznaczyli tylko, że Piotr szedł z daleka i wszedł na dziedziniec arcykapłana, po czym zaprezentowali opis żydowskiego procesu Jezusa, a następnie trzykrotne zaparcie się Piotra (Mk 14,53-54.55-65.66-72; Mt 26,57-58.59-68.69-75). Autor Ewangelii według św. Łukasza uczynił to natomiast w odwrotnej kolejności: napomknął o wejściu pojmanego Jezusa do domu arcykapłana, po czym ukazał epizod z Piotrem wypierającym się swego Mistrza, a na koniec przesłuchanie Jezusa przez kapłana (Łk 22,54.55-62.63-71). U Jana mamy do czynienia z mistrzowskim zastosowaniem techniki interpolacji (określanej w narratologii także jako sandwich (ponieważ opiera się ona na strukturze $\left.\mathrm{ABA}^{\prime}\right]$ ): scena przesłuchania Jezusa pojawia się dopiero po pierwszym zaparciu się Piotra, zatrzymując na chwilę toczącą się na dziedzińcu akcję i dając jej potem możliwość powrotu na swoje tory dzięki powtórzonej sekwencji mówiącej o grzaniu się Piotra przy ogniu. Owo ponowne przytoczenie (niemal) identycznych słów to figura określana mianem epanálēpsis (Wiederaufnabme) (por. Neirynck, „L'epanálēpsis”, 303, 309). Tak skonstruowana narracja wzmacnia efekt sýnkrisis, a więc „porównania, zestawienia ze sobą” zachowania Jezusa i Piotra, dzięki także wyeksponowaniu postaw i słów tych postaci kontrastujących ze sobą.

40 Escaffre, „Pierre”, 57 („ce chant du coq [...] est [...] la dernière «voix» de l'épisode").

41 Warto zauważyć, że po uprzednim, dwukrotnym przytoczeniu słów „nie jestem” w mowie niezależnej (J 18,17.25) za trzecim razem negatywna odpowiedź ucznia zostaje podana już tylko przez narratora: „Piotr znowu zaprzeczyl” (J 18,27), nie dając czytelnikowi możliwości „usłyszenia” jego głosu. U synoptyków natomiast trzecia, definitywna odpowiedź Piotra „wybrzmiewa” bardzo wyraźnie poprzedzona na dodatek pełną dynamizmu dramatyczną jego reakcją (por. Mt 26,74: „Wtedy począł się zaklinać i przysięgać: «Nie znam tego Człowieka». I w tej chwili kogut zapiał”, Mk 14,71-72a: „Lecz on począł się zaklinać i przysięgać: «Nie znam tego człowieka, o którym mówicie». I w tej chwili kogut powtórnie zapiał”, Łk 22,60: „Piotr 
zastąpione nieprzyjemnym, skrzeczącym dźwiękiem ptaka ${ }^{42}$, wpisuje się tym samym w koncepcję ironii Janowej, obecnej na przestrzeni całej Ewangelii. Pierwszy z apostołów zamiast potwierdzić swą tożsamość ucznia ${ }^{43}$, truchleje wobec sług arcykapłana. Ten, który zapewniał o gotowości na śmierć z Jezusem, w momencie próby nie potrafi się przyznać, że był razem z Nim w ogrodzie (J 18,26-27).

Można by odebrać wrażenie, że uwaga czytelnika Ewangelii skupia się na koniec na postaci koguta. Niezupełnie jednak jest to prawdą. Chociaż nasza myśl nie koncentruje się tak bardzo na osobie Piotra, jak to miało miejsce podczas lektury Ewangelii synoptycznych ${ }^{44}$, to jednak kogut nie tyle sam w sobie, co jego funkcja narracyjna sprawia, że na pierwszy plan wysuwa się osoba Jezusa oraz kwestia realizującego się proroctwa wypowiedzianego przez Niego w J 13,38. Czytelnik dzieła Janowego dochodzi bowiem do wniosku, że Chrystus jest prawdziwym Prorokiem, którego słowo ma moc i wypełnia się w każdym szczególe ${ }^{45}$. Dojście do takiej konkluzji rodzi z kolei pewną nadzieję: skoro zrealizowała się zapowiedź trzykrotnego wyparcia się Mistrza przez Piotra, to równie precyzyjnie powinno wypełnić się także inne pro-

zaś rzekł: «Człowieku, nie wiem, co mówisz». I w tej chwili, gdy on jeszcze mówił, kogut zapiał").

42 Escaffre, „Pierre”, 58 („Pierre ne fait plus rien, ne dit plus un mot, ne se rappelle rien, ni n'exprime de remords. Il laisse la parole à un coq)".

43 Czwarta Ewangelia kładzie nacisk na temat uczniów także w opisie Męki Pańskiej. W odróżnieniu od relacji synoptyków Piotr dwukrotnie został zapytany o to, czy jest uczniem Jezusa (J 18,17.25). Kompleksowo omawia tę problematykę monografia: Grochowski, Il discepolo di Gesù.

44 Jego żal był w końcu przejmujący i godzien uznania.

45 Ellis, The Genius of John, 254 („emphasis on Jesus as a true prophet whose foretelling of Peter's denial (cfr. 13:38) was fulfilled to the letter”), Moloney, The Gospel of John, 491-492 („The fulfillment of Jesus' prophecy in 13:38 is fundamental to the message of part of the passion story"). 
roctwo, obwieszczone uczniowi w tym samym kontekście podczas Ostatniej Wieczerzy. Chwilę wcześniej (J 13,36) Piotr usłyszał mianowicie zapowiedź przyszłego, tym razem już skutecznego, pójścia za Jezusem, a więc utwierdzenia się w swej tożsamości Jego autentycznego ucznia ${ }^{46}$. Dokona się to w pewnej nieokreślonej przyszłości, której znamiona zostaną przedstawione apostołowi niedługo po zmartwychwstaniu Jezusa.

Okazuje się, że także w Ewangelii Janowej św. Piotr będzie miał swoją okazję do rehabilitacji. Nie zapłakał on bezpośrednio po wyparciu się Jezusa, ale później, nad Jeziorem Tyberiadzkim, na pytanie Mistrza o miłość, odpowiedział szczerze, że Go kocha, a za trzecim razem został nawet ogarnięty głębokim smutkiem (J 21,15-17). Nietrudno jest się domyśleć, że skojarzył on trzykrotność pytań Jezusa z taką samą liczbą pytań postawionych mu na dziedzińcu arcykapłana $^{47}$. Dodatkowym znakiem rozpoznawczym dla Piotra (gnốrisma) jest w czwartej Ewangelii anthrakiá, a więc „ogień rozpalony na węglu drzewnym" (J 18,18; 21,9). Również ten tak bardzo precyzyjnie określony szczegół musiał go zainspirować do wzbudzenia żalu za nieokazanie wierności

46 J 13,36: „Dokąd Ja idę, ty teraz za Mną pójść nie możesz, ale później pójdziesz". Występujący tu dwukrotnie czasownik akolouthéo, oprócz określania fizycznego „ruchu postępującego za kimś”, wyraża także ideę przybrania "postawy uczniowskiej”. To metaforyczne znaczenie słowa jest charakterystyką właściwą nie tylko judaizmowi czy chrześcijaństwu, lecz znane było także choćby w starożytnej Grecji (Kittel, „akolouthéō, 567-579).

47 Należy podkreślić fakt, że tylko św. Jan prezentuje pytania skierowane do Piotra przez sługi arcykapłana (por.J 18,17.25-26). U synoptyków mamy do czynienia ze zdaniami orzekającymi lub wykrzyknikowymi (por. Mk 14,67.69-70; Mt 26,69.71.73; Łk 22,56.58-59). Nie jest to celem niniejszego opracowania, ale ciekawostkę może stanowić spostrzeżenie, że wszystkie te pytania zaadresowane do Piotra (zarówno trzy wypowiedziane przez sługi arcykapłana, jak i trzy sformułowane przez Jezusa nad Jeziorem Galilejskim) mają charakter retoryczny (por. Grochowski, „Nawrócenie św. Piotra”, 57-65). 
Chrystusowi tej pamiętnej, smutnej nocy ${ }^{48}$. Szczera miłość ucznia do Pana, choć wciąż krucha i niedoskonała, staje się wystarczającą podstawą, by powierzyć mu misję pasterską oraz powołać do pójścia śladami Mistrza także w chwalebnym męczeństwie. Skoro fakt ten zapowiada sam Jezus ${ }^{49}$, to nie ulega wątpliwości, że Piotr rzeczywiście pójdzie tą drogą i dzięki temu odpokutuje swój „upadek” oraz będzie zrehabilitowany. Bo jak spełniła się zapowiedź wyparcia się Mistrza i towarzyszące temu pianie koguta (J 13,38), tak teraz spełni się również drugie proroctwo mówiące o tym, że Piotr stanie się autentycznym uczniem Jezusa (J 13,36).

\section{Podsumowanie}

Dziki ptak Gallus gallus, z czasem udomowiony (domesticus) i rozpowszechniony po świecie, stał się bardzo popularnym źródłem smacznego mięsa i jaj. Bogata symbolika z nim związana zainspirowała autorów ST do zauważenia w nim zdolności do odróżniania dnia od nocy (por. Hi 38,36; 3 Mch 5,23 LXX) oraz troskliwej (a także dumnej) opiekuńczości względem powierzonych mu kur (por. Prz 30,31 LXX). Jednak kogut najbardziej jest znany z wydarzenia opisanego w NT. Wpisał się bowiem w epizod związany z Męką Pańską, gdy, zgodnie z przepowiednią Jezusa (por. Mt 26,34; Mk 14,30; Łk 22,34; J 13,38), swoim pianiem uwieńczył niechlubną postawę św. Piotra (por. Mt 26,69-75; Mk 14,66-72; Łk 22,54-62; J 18,15-27).

48 Por. Grochowski, „Nawrócenie św. Piotra”, 69-70.

49 Por. J 13,36 i 21,18-19: „Zaprawdę, zaprawdę, powiadam ci: Gdy byłeś młodszy, opasywałeś się sam i chodziłeś, gdzie chciałeś. Ale gdy się zestarzejesz, wyciągniesz ręce swoje, a inny cię opasze i poprowadzi, dokąd nie chcesz». To powiedział, aby zaznaczyć, jaką śmiercią uwielbi Boga. A wypowiedziawszy to rzekł do niego: «Pójdź za Mną!»”. Manns, „Les mots”, 295 („le verbe akoloutheō [...] en 13,36 aura un sens nouveau et désignera le martyre de Pierre”). 
Warto jednak zauważyć, że podczas gdy w Ewangeliach synoptycznych kogut stał się znakiem rozpoznawczym (gnốrisma) uświadamiającym Piotrowi popełniony błąd i wzywającym go skutecznie do wzbudzenia natychmiastowego żalu, tak u św. Jana jego pianie jawi się jako ironiczny i smutny „ostatni głos epizodu”, a dla czytelnika staje się znakiem wskazującym na Jezusa jako Proroka pełnego mocy w swym słowie. Dzięki temu rodzi się jednocześnie nadzieja, że skoro precyzyjnie zrealizowała się zapowiedź tego dramatycznego wydarzenia, tak też z pewnością dojdzie do skutku przepowiednia męczeństwa św. Piotra (J 13,36; 21,18-19). Dzięki niemu jego upadek będzie w pełni odpokutowany, a apostoł, który stanie się przez to autentycznym uczniem Jezusa, będzie zrehabilitowany.

\section{BiBLIOGRAFIA}

Abramowiczówna Z., „aléktōr”, Stownik grecko-polski (red. Z. Abramowiczówna) (Warszawa: PWN 1958) I, 83.

Abramowiczówna Z., „alektryốn”, Stownik grecko-polski (red. Z. Abramowiczówna) (Warszawa: PWN 1958) I, 83.

Al-Nasser A. et al., „Overview of Chicken Taxonomy and Domestication", World's Poultry Science Journal 63/2 (2007) 285-300.

Aretius B., In Novum Testamentum Domini nostri Iesu Christi Commentarii Doctissimi Benedicti Aretii Bernesis Theologi praestantissimi, facili perspicuaque methodo conscripti (Genevae: Apud Petrum et Jacobum Chouët 1618).

Bauckham R., The Jewish World around the New Testament. Collected Essays (Grand Rapids, MI: Baker Academic, a Division of Baker Publishing Group 2010).

Behrouzi N., „Costume, Jewish”, Encyclopedia of Modern Jewish Culture (red. G. Abramson) (London - New York, NY: Routledge 2005) I, 264-271. 
Brown R.E., The Death of the Messiah. From Gethsemane to the Grave. A Commentary on the Passion Narratives in the Four Gospels (New York, NY - London - Toronto - Sydney Auckland: Doubleday 1994) I.

Cansdale G., Animals of Bible Lands (Sydney - Toronto - Auckland - Cape Town: The Paternoster Press 1970).

Cicero M.T., De Senectute. De Amicitia. De Divinatione. In TwentyEight Volumes. XX. with an English Translation by William Armistead Falconer (Loeb Classical Library 154; Cambridge, MA - London: Harvard University Press 1979).

Clines D.J.A., "geber”, The Dictionary of Classical Hebrew (red. D.J.A. Clines) (Sheffield: Sheffield Academic Press 1995) II, 313-314.

Clines D.J.A., „śekwî”, The Dictionary of Classical Hebrew (red. D.J.A. Clines) (Sheffield: Sheffield Phoenix Press 2011) VIII, 148. Clines D.J.A., „zarzîr”, The Dictionary of Classical Hebrew (red. D.J.A. Clines) (Sheffield: Sheffield Academic Press 1996) III, 137.

Cooper J.C., Zwierzęta symboliczne i mityczne (Poznań: Dom Wydawniczy Rebis 1998).

Derrett J. - Duncan M., "The Reason for the Cock-Crowings”, New Testament Studies 29 (1983) 142-144.

Ellis P.F., The Genius ofJohn. A Composition-Critical Commentary on the Fourth Gospel (Collegeville, MN: Liturgical Press 1984). Escaffre B., „Pierre et Jésus dans la cour du grand prêtre (Jn 18,1227)", Revue Théologique de Louvain 31 (2000) 43-67.

Feliks J., The Animal World of the Bible (Tel Aviv: Sinai 1962). Feliks J., „Chicken”, Encyclopaedia Judaica (red. F. Skolnik M. Berenbaum) (Detroit et al:: Thomson Gale $\left.{ }^{2} 2007\right)$ IV, 613. Firmage E., "Zoology”, The Anchor Bible Dictionary (red. D.N. Freedman et al.) (New York: Doubleday 1992) VI, 1109-1167. France P., An Encyclopaedia of Bible Animals (Tel Aviv: Steimatzky 1986).

Ginzberg L., The Legends of the Jews, I: Bible Times and Characters from the Creation to Jacob (tłum. H. Szold) (Philadelphia: The Jewish Publication Society of America 1909). 
Grochowski Z., Il discepolo di Gesú nell'ora della prova (Gv 18-19), luogo di rivelazione del Maestro (Studia Biblica Lublinensia 13; Lublin: Wydawnictwo KUL 2015).

Grochowski Z., „Nawrócenie św. Piotra w czwartej Ewangelii (J 21,1-19). «Rehabilitacja» ucznia po trzykrotnym zaparciu się Mistrza”, Studia z biblistyki. Tom 9 (red. R. Bartnicki) (Warszawa: Wydawnictwo Naukowe UKSW 2016) 51-72. Jeremias J.,Jerusalem zur Zeit Jesu. Kulturgeschichtliche Untersuchung zur neutestamentlichen Zeitgeschichte (Göttingen: Vandenhoeck \& Ruprecht ${ }^{2}$ 1958).

Kittel G., „akolouthéo”, Grande Lessico del Nuovo Testamento (red. G. Kittel - G. Friedrich; tłum. F. Montagnini - G. Scarpat) (Brescia: Paideia 1965) I, 567-579.

Kobielus S., Bestiarium chrześcijańskie. Zwierzęta w symbolice i interpretacji. Starożytność i średniowiecze (Warszawa: Instytut Wydawniczy Pax 2002).

Kosmala H., „The Time of the Cock-Crow”, Annual of the Swedish Theological Institute (in Jerusalem) 2 (1963) 118-120.

Kosmala H., „The Time of the Cock-Crow (II)”, Annual of the Swedish Theological Institute (in Jerusalem) 6 (1968) 132-134. Kowzan J., „Kogut, czyli przyczynek do pewnej zwierzęcej ambiwalencji w kulturze", Bestie, żywy inwentarz i bracia mniejsi. Motywy zwierzęce w mitologiach, sztuce i życiu codziennym (red. P. Kowalski - K. Łeńska-Bąk - M. Sztandara) (Stromata Anthropologica 1; Opole: Wydawnictwo Uniwersytetu Opolskiego 2007) 121-132.

Lagrange M.J., Évangile selon Saint Marc (Études Bibliques; Paris: Gabalda ${ }^{5}$ 1929).

Lagrange M.J., L'Évangile de Jésus-Christ avec la synopse évangélique (Études Bibliques; Paris: Gabalda 1954).

Lasota-Moskalewska A., Zwierzęta udomowione w dziejach ludzkości

(Warszawa: Wydawnictwo Uniwersytetu Warszawskiego 2005). Lattey C., „A Note on Cockcrow”, Scripture 6 (1954) 53-55. Liddell H.G. - Scott R. - Jones H.S. - McKenzie R., A GreekEnglish Lexicon. With a Revised Supplement (Oxford: Clarendon Press 1996). 
Liu Y.P. et al., „Multiple Maternal Origins of Chickens: Out of the Asian Jungles", Molecular Phylogenetics and Evolution 38/1 (2006) 12-19.

Manns F., „Les mots à double entente. Antécédents et function herméneutique d'un procédé johannique", L'Évangile de Jean à la lumière du Judaïsme (red. F. Manns) (Studii Biblici Franciscani Analecta 33; Jerusalem: Franciscan Printing Press 1991) 289-306.

Mayo C.H., „St. Peter's Token of the Cock Crow”, Journal of Tamil Studies 22 (1921) 367-370.

Martin T.W., „Watch during the Watches (Mark 13:35)”, Journal of Biblical Literature 120/4 (2001) 685-701.

Mędala S., Ewangelia wedtug świętego Jana. Rozdziaty 13-21

(Nowy Komentarz Biblijny Nowy Testament 4b; Częstochowa: Edycja Świętego Pawła 2010).

Moloney F.J., The Gospel of John (Sacra Pagina Series 4; Collegeville, MN: Liturgical Press 1998).

Montanari F., „aléktōr”, Vocabolario della lingua greca (red. F. Montanari) (Torino: Loescher 1995) 123.

Montanari F., „aléksō”, Vocabolario della lingua greca (red. F. Montanari) (Torino: Loescher 1995) 123-124.

Morris L., The Gospel According to John. Revised Edition (New International Commentary on the New Testament; Grand Rapids, MI: Eerdmans Publishing Company 1995).

Moulton J.H. - Howard W.F., A Grammar of New Testament Greek, Vol. II: Accidence and Word-Formation with the Appendix on Semitisms in the New Testament (Edinburgh: T\&T Clark 1996). Neirynck F., „L'epanalepsis et la critique littéraire. À propos de l'Évangile de Jean', Ephemerides Theologicae Lovanienses 56 (1980) 303-338.

Paczkowski M.C., „Czujny zwiastun brzasku i zmartwychwstania.

Kogut w symbolice starochrześcijańskiej", Biblica et Patristica Thoruniensia 7/4 (2014) 77-95.

Perry-Gal L. - Erlich A. - Gilboa A. - Bar-Oz G., „Earliest Economic Exploitation of Chicken outside East Asia: Evidence from the Hellenistic Southern Levant", Proceedings of the 
National Academy of Sciences of the United States of America 112/32 (2015) 9849-9854.

Pesch R., Il vangelo di Marco. Parte seconda. Testo greco e traduzione. Commento ai capp. 8,27-16,20 (red. O. Soffritti; thum.

M. Soffritti) (Commentario Teologico del Nuovo Testamento II/2; Brescia: Paideia 1982).

Rocci L., „aléktōr”, Vocabolario greco italiano (red. L. Rocci)

(Roma: Società Editrice Danti Alighieri $\left.{ }^{37} 1993\right) 66$.

Rocci L., ,aléksō”, Vocabolario greco italiano (red. L. Rocci) (Roma:

Società Editrice Danti Alighieri ${ }^{37}$ 1993) 67.

Romizi R., „aléktōr”, Greco antico. Vocabolario Greco italiano etimologico e ragionato (red. R. Romizi) (Bologna: Zanichelli $\left.{ }^{3} 2007\right) 57$.

Scherman N. - Goldwurm H. - Gold A., Jom Kippur - Its

Significance, Laws, and Prayers. A Presentation Anthologized from Talmudic and Traditional Sources (Artscroll Mesorah

Series; New York, NY: Mesorah Publications 1989).

Spiciarich A. - Gadot Y. - Sapir-Hen L., „The Faunal Evidence from Early Roman Jerusalem: The People behind the Garbage", Tel Aviv 44/1 (2017) 98-117.

Tixier-Boichard M. - Bed'hom B. - Rognon X., „Chicken

Domestication: From Archeology to Genomics", Comptes Rendus Biologies 334/3 (2011) 197-204.

Wajda A.M., ,Wybrane zagadnienia z ornitologii biblijnej na warsztacie thumacza i egzegety", Zeszyty Naukowe Stowarzyszenia Biblistów Polskich 14 (2017) 453-476.

West B. - Zhou B.X., „Did Chickens Go North? New Evidence for Domestication", Journal of Archaeological Science 15/5 (1988) 515-533.

Worcester J., Correspondences of the Bible. The Animals (Boston, MA: Massachusetts New Church Union 1926).

Ks. ZBIGNiew GRochowski, prezbiter diecezji elbląskiej, doktor nauk biblijnych i archeologii, absolwent rzymskiego Pontificium Institutum Biblicum (licencjat) i jerozolimskiego Studium Biblicum 
Franciscanum (doktorat), adiunkt w Katedrze Historii Biblijnej Instytutu Nauk Biblijnych Wydziału Teologicznego Uniwersytetu Kardynała Stefana Wyszyńskiego w Warszawie. Zajmuje się pismami Janowymi i tematem uczniów Jezusa. Wykładowca w WSD w Elblągu (a w latach 2013-2016 także w Telewizyjnym Uniwersytecie Biblijnym TV „Trwam”), członek zwyczajny Stowarzyszenia Biblistów Polskich i Stowarzyszenia Ex-Alunni PIB. Opublikował monografię Il discepolo di Gesù nell'ora della prova (Gv 18-19), luogo di rivelazione del Maestro (Studia Biblica Lublinensia 13; Lublin: Wydawnictwo KUL 2015). 